\title{
The Future of Child Refugees in Europe
}

\author{
Agatha Lydia Natania \\ 2014330035 \\ Mahasiswa Ilmu Hubungan Internasional, Fakultas Ilmu Sosial dan Ilmu Politik \\ Universitas Katolik Parahyangan
}

\begin{abstract}
Abstrak
Krisis pengungsi yang terjadi di Eropa telah menarik perhatian dunia internasional. Di antara berbagai pengungsi dengan latar belakang yang berbeda-beda, banyak anak terpaksa meninggalkan negaranya dan menempuh jalan yang berbahaya agar sampai di tanah Eropa. Bahkan, banyak dari antara mereka tidak pernah sampai di tempat tujuannya atau kehilangan anggota keluarganya. Berdasarkan pentingnya jaminan keamanan dan keselamatan para pengungsi anak-anak tersebut, karya tulis ini akan fokus pada pemetaan kebutuhan mereka. Argumen utama pada karya tulis ini adalah kondisi pemenuhan kebutuhan para pengungsi anak-anak tidak merata, sehingga diperlukan adanya tindakan terkoordinasi antara para pemangku kepentingan untuk menjamin keselamatan para pengungsi anak-anak ini. Selain itu, pentingnya aspek pendidikan juga akan dibahas untuk menekankan pentingnya perencanaan masa depan mereka. Karya tulis ini akan menggunakan teori keamanan manusia untuk menjelaskan hak para pengungsi anak-anak untuk mendapatkan pemenuhan kebutuhan mereka. Pemenuhan kebutuhan pengungsi anakanak perlu dipertimbangkan secara menyeluruh dan dikoordinasikan dengan baik.
\end{abstract}

Kata kunci: pengungsi, anak, keamanan manusia, pendidikan

\section{Introduction}

The refugee influx in Europe is regarded as the worst humanitarian crisis after the second world war. It is reported that since the beginning of 2014, approximately 800,000 people arrived at the European Union borders through illegal channels and dangerous route in order to find a better life in Europe. ${ }^{1}$ In 2015, the United Nations High Commissioner for Refugees (UNHCR) reported that $1,000,573$ refugees and migrants have reached Europe by sea. ${ }^{2}$ As a response to the

1 Victoria Metcalfe-Hough, "The migration crisis? Facts, challenges, and possible solutions," ODI Briefing, October 2015.

2 Jonathan Clayton and Hereward Holland, "Over one million sea arrivals reach Europe in 2015," UNHCR official website, December 30, 2015, accessed November 20, 2017,

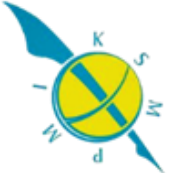


increasing number of refugee influx, a joint statement by the International Organization for Migration (IOM) and UNHCR emphasized the effort to conduct a "more coordinated European response." 3 Previously, a lot of studies and researches have been conducted to analyze the issue of refugees in Europe. For instance, Nicole Ostrand has conducted a research about the Syrian Refugee Crisis: A comparison of responses by Germany, Sweden, the United Kingdom and the United States. ${ }^{4}$ Ostrand focused on the burdens and costs of the Syrian refugee crisis and how they are shared by the international community, particularly by the abovementioned states. ${ }^{5}$ Another research has been conducted by Carrera, Blockmans, Gros, and Guild on the EU's response to the refugee crisis: taking stock and setting policy priorities. ${ }^{6}$ The research examines the EU's policy and legislative initiatives and identifies the existing challenges. ${ }^{7}$ Different than those two researches, this essay focuses on the issue of child refugees, particularly on the aspect of protection and the fulfillment of their needs.

Among the refugees who tried to reach European soil, there are child refugees who take the same journey with them. The definition of child refugees is included at the 1951 Refugee Convention and the 1967 Protocol (Relating to the Status of Refugees), which is applied in the same way as to adults: "1) a child who has a "well-founded fear of being prosecuted" for one of the stated reasons is a "refugee"; 2) a child who holds refugee status cannot be forced to return to the country of origin (the principle of non-refoulement), and 3) no distinction is made

http://www.unhcr.org/afr/news/latest/2015/12/5683d0b56/million-sea-arrivals-reach-europe2015.html

3 "Migrant crisis: One million enter Europe in 2015," BBC News, December 22, 2015, accessed on November 21, 2017, http://www.bbc.com/news/world-europe-35158769

${ }^{4}$ Nicole Ostrand, "The Syrian Refugee Crisis: A Comparison of Responses by Germany, Sweden, the United Kingdom, and the United States," Journal on Migration and Human Security 3, no. 3 (2015): 255-279.

${ }^{5}$ Ibid.

${ }^{6}$ Sergio Carrera, et al., "The EU's Response to the Refugee Crisis: Taking Stock and Setting Policy Priorities," Centre for European Policy Studies Essay no. 20 (December 2015): 1-2.

${ }^{7}$ Ibid. 
between children and adults in social welfare and legal rights." ${ }^{\prime 8}$ According to UNICEF, 93,066 children have arrived in Europe by sea between January and December 2016. ${ }^{9}$ However, not every child is travelling with the family, there are a lot of child refugees who are travelling alone. Those children might be travelling alone since the beginning of the journey, or might lost their family members along the journey to Europe. They are categorized as 'unaccompanied refugees.' European Union defines unaccompanied minor (UAM) as "a minor who arrives on the territory of a European Union Member State unaccompanied by an adult responsible or who is left unaccompanied after he or she has entered the territory of the member states." 10 According to the International Organization for Migration (IOM), there is another case when a child arrives with an adult without uncertain relations, which might be the case of child marriage, which is defined as 'accompanied non accompanied.' ${ }^{11}$ For instance, UNICEF reported that there are 25,846 children who arrived by sea in Italy between January and December 2016, that are unaccompanied and separated. ${ }^{12}$

Based on the report from (UNHCR), the Syrian child refugees are suffering from losing their family members, friends and future. ${ }^{13}$ Furthermore, they are wounded physically and psychologically. Save the Children informed that among

\footnotetext{
${ }^{8}$ UNHCR, "Refugee Children: Guidelines on Protection and Care," accessed November 18, 2017, http://www.unhcr.org/protect/PROTECTION/3b84c6c67.pdf

${ }^{9}$ UNICEF, "Refugee and Migrant Crisis in Europe: Humanitarian Situation Report \#19," January 16, 2017, accessed on November 18, 2017, https://www.unicef.org/appeals/files/UNICEF_Refugee_and_Migrant_Crisis_in_Europe_R egional_Humanitarian_Situation_Report_16_Jan_2017.pdf

10 International Organization for Migration Global Migration Data Analysis Centre, "Children and unsafe migration in Europe: Data and policy, understanding the evidence base," accessed November 20, 2017, https://publications.iom.int/system/files/gmdac_data_briefing_series_issue5.pdf, 1 .

${ }^{11}$ Ibid.

${ }^{12}$ UNICEF, "Refugee and Migrant Crisis in Europe: Humanitarian Situation Report \#19," $\begin{array}{lllll}\text { January } & \text { 20, } & \text { 2017, } & \text { accessed }\end{array}$ https://www.unicef.org/appeals/files/UNICEF_Refugee_and_Migrant_Crisis_in_Europe_R egional_Humanitarian_Situation_Report_16_Jan_2017.pdf

${ }^{13}$ UNHCR, "The Future of Syria: Refugee Children in Crisis," November 2013, accessed November 18, 2017, http://www.refworld.org/pdfid/529c3b4d4.pdf
} 
21.3 million refugees in the world, half of them are children. A lot of them have experienced physical and emotional traumas, missed years of school, travelled alone and starved along the journey from their home country. UNICEF also reported that they are exhausted and have trouble sleeping during the journey to reach the host country. ${ }^{14}$ The children also expressed their feelings that they feel cold at night and sometimes stuck in wet clothes for hours after it rains. ${ }^{15}$ In addition, they are also afraid that they might be arrested, trafficked or sent back to their home country. ${ }^{16}$ They said that they miss their home and play with their friends, and they hope to be able to go to school again and sleep in a bed. ${ }^{17}$

The child refugees are also prone to have mental health problems which were caused by the experiences prior and/or the journey to Europe. ${ }^{18}$ Each child refugees faced different situations, meaning that the assistance has to take into account their background, such as their country of origin, their flight experience and post-flight experience which may include separation experiences (where the child lost their parents or family members), sexual abuse, human trafficking (including forced labor and sexual exploitation). ${ }^{19}$ The issues are still rising even when they already arrived at the host country. For instance, the unsafe and problematic living condition, insecurity regarding to their status, lack of access to education, multiple

${ }^{14}$ UNICEF, "Refugee and Migrant Crisis in Europe," September 2015, accessed November 20 , 2017 , https://www.unicef.org/publicpartnerships/files/Refugee_and_migrant_children_in_Europe_ -_Sept_2015.pdf

15 Ibid.

16 Ibid.

${ }^{17}$ Ibid.

${ }^{18}$ Johannes Hebebrand, et al., "A first assessment of the needs of young refugees arriving in Europe: what mental health professionals need to know, Eur Child Adolesc Psychiatry, (2016)25:

$1-6$, https://www.escap.eu/bestanden/Care\%20(38)/Refugees/REFUGEE\%20CRISIS/refugee_ed itorial_january_2016.pdf

${ }^{19}$ Ibid.

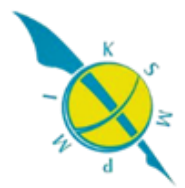


moves, social exclusion, illness, unemployment, and medium- and long-term adaptation to the cultural norms of the hosting country. ${ }^{20}$

\section{Human Security Theory}

Human security can be defined as "... to protect the vital core of human lives in ways that enhance human freedoms and human fulfillment" and brings the human elements of security, rights, and development, with the characteristics of people-centered, multi-sectoral, comprehensive, context-specific, preventionoriented. ${ }^{21}$ In the case of child refugees, the type of security that might threaten their living condition is in terms of food security (hunger, famine), health security (deadly infectious diseases, unsafe food, malnutrition, lack of access to basic health care), personal security (physical violence, crime, child labor), and political security (political repression, human rights abuses). ${ }^{22}$ It is argued that human security emphasizes that threats and responses are interconnected in two ways. The first one is that each threat feeds on the other, for instance, human rights abuses may result in poverty, which later causes hunger, and malnutrition. The second is that threats within a country or an area can spread into a wider region and have negative impacts for the regional and international security. ${ }^{23}$

\section{The Fulfillment of Child Refugees' Needs: Protection and Education}

The issue of child refugees is considered as a human security issue because of the lack of protection to their vital condition. As what has been described in the previous section, in the sector of food security, a lot of child refugees are

\footnotetext{
${ }^{20}$ Ibid.

${ }^{21}$ United Nations Trust Fund for Human Security, "Human Security in the theory and practice: An overview of the Human Security Concept and the United Nations Trust Fund for Human Security." 2009. http://www.un.org/humansecurity/sites/www.un.org.humansecurity/files/human_security_in _theory_and_practice_english.pdf

${ }^{22}$ Ibid.

${ }^{23}$ Ibid.
} 
experiencing hunger. While in the sector of health security, a lot of child refugees are struggling with malnutrition, deadly infectious diseases, and lack of access to basic health care. Moreover, the child refugees are also struggling from personal security that include physical violence, crime, child labor. Based on the $10^{\text {th }}$ European Forum on the rights of the child, with the theme of the protection of children in migration, several existing problems among the child refugees are as follows: i) lack of respect of the child's right to primary consideration of their best interests; ii) dangers when crossing EU external borders, which may include transactional sex to finance the journey; iii) separation along the way to the host country; iv) lack of access to protection; v) lack of mechanism and response at the reception centers; vi) risk of sexual violence, sexual exploitation, and trafficking along the route to the host country and in the reception; vii) lack of access to reliable information, advice, and access to child-specific information information in child-friendly manner; viii) lack of, or limited access to education and adequate healthcare, including psychosocial care, and family reunification, ix) lack of specialized care on arrival for the children who are traumatized and did not have access to healthcare on the journey; $\mathrm{x}$ ) gaps caused by lack of coordinated between various services and agencies who are involved in the treatment of children in migration. ${ }^{24}$

This paper will take a closer look on the fulfillment of the child refugees needs, which is categorized into two main issues faced by them, which are the issue of protection and education. First and foremost, the protection of child refugees should be prioritized. The European Union (EU) sees that protecting the child refugees is the real action of European values of human rights, dignity and solidarity. ${ }^{25}$ In addition, the EU also considers the protection of the children at all

\footnotetext{
${ }^{24} 10^{\text {th }}$ European Forum on the rights of the child, "The protection of children in migration," 29-30 November 2016, revised on March 29, 2017.

25 European Commission, "Communication from the Commission to the European Parliament and the Council: The protection of children in migration," 2017, https://ec.europa.eu/home-affairs/sites/homeaffairs/files/what-we-do/policies/european-
}

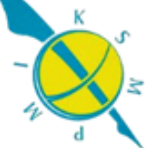


stages of migration as a priority, regardless of their status. The fundamental reasons why these child refugees have to be protected are because of their traumatic experiences in the home country, along the journey to Europe, and the condition at the refugee camps. The EU reported that they are often to be at risk and suffer from "extreme forms of violence, exploitation, trafficking in human beings, physical, psychological and sexual abuse" prior to their arrival and/or after their arrival in EU territory. ${ }^{26}$

According to EU, as a form of protection, child refugees should be identified, registered as children in the EU's data, and be prioritized in all borderrelated procedures. ${ }^{27}$ In the sector of protection, UNICEF has conducted efforts in several host countries. For instance, in Croatia, UNICEF monitors and responds to child refugees needs by giving an integrated package of activities (child-friendly activities) in the asylum centres and also providing regular counselling on health and protection issues, and activities for children who have started school. ${ }^{28}$ In Slovenia, UNICEF has mapped the child protection system which includes child participation, guardianship, capacity-building of frontline workers and institutional and legislative reforms. ${ }^{29}$ UNICEF has conducted efforts to assist the child refugees through advocacy, to provide assistances to the government and general assistances to meet the need of child refugees in the field, and to enhance the capacity-building and proactive systems for the child refugees. ${ }^{30}$ Other efforts that have been done are safeguarding and family reunification processes. As written on "Refugee Children: Guidelines on Protection and Care," the child refugees are not only prone to be at

agenda-

migration/20170412_communication_on_the_protection_of_children_in_migration_en.pdf,

2.

${ }^{26}$ Ibid.

${ }^{27}$ Ibid., 6.

${ }^{28}$ UNICEF, "Refugee and Migrant Crisis in Europe: Humanitarian Situation Report \#19," $\begin{array}{lllll}\text { January } \quad 16, \quad 2017, \quad \text { accessed } & \text { November }\end{array}$ https://www.unicef.org/appeals/files/UNICEF_Refugee_and_Migrant_Crisis_in_Europe_R egional_Humanitarian_Situation_Report_16_Jan_2017.pdf

${ }^{29}$ Ibid.

${ }^{30}$ Ibid. 
risk, but they also need special attention. ${ }^{31}$ Based on this condition, the UNHCR sees the urgency to enhance their protection and well-being by adopting a Policy on Refugee Children, which was endorsed by the UNHCR Executive Committee in 1993. ${ }^{32}$ UNICEF has responded by providing equipment at the main reception centre in the former Yugoslav Republic of Macedonia to improve access to water and also established child-friendly centres. ${ }^{33}$ In Serbia, other than a child-friendly space, UNICEF also provide educational materials and toys for the children, and provide guidance on child health and nutrition, hygiene and safety issues to the parents. ${ }^{34}$

The protection of the refugees is the responsibility of the state. For states who have already signed the 1951 Convention, they are obliged to protect the refugees in accordance to the terms in the convention..$^{35}$ However, in the reality, there is a major absence of protection from some European states to the refugees. For instance, Macedonia, Croatia and Slovenia, even tighten their borders so that the refugees can not enter the country's territory. ${ }^{36}$ Based on this condition, it can be seen that a country that should have become the actor who protect the refugees, does not comply to its obligation and abandons them instead. The refugees who have been through such a long journey to get into the host country were rejected and forced to go through another long journey to find a host country that would received them. This is the reason why the issue of protection to the refugees, particularly

${ }^{31}$ UNHCR, "Refugee Children: Guidelines on Protection and Care," accessed November 18, 2017, http://www.unhcr.org/protect/PROTECTION/3b84c6c67.pdf

${ }^{32}$ Ibid.

${ }^{33}$ UNICEF, "Refugee and Migrant Crisis in Europe," September 2015, accessed November 20 , 2017 , https://www.unicef.org/publicpartnerships/files/Refugee_and_migrant_children_in_Europe_ -_Sept_2015.pdf

${ }^{34}$ Ibid.

${ }^{35}$ UNHCR, "Protecting Refugees: A field guide for NGOs," accessed November 28, 2017, http://www.unhcr.org/3bb9794e4.pdf

${ }^{36}$ Patrick Kingsley, "Balkan countries shut borders as attention turns to new refugee routes," The Guardian, March 9, 2016, accessed November 28, 2017, https://www.theguardian.com/world/2016/mar/09/balkans-refugee-route-closed-sayeuropean-leaders

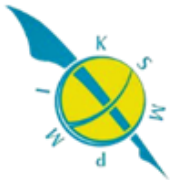


child refugees, should not be obliged solely to the countries. They are not the only actor that could give protection to the refugees. International organization and other entities who are willing to help the refugees are also considered as the main actor and therefore should cooperate with the countries in ensuring the protection of the refugees. In the case where there is an absence of protection from the host country, international organizations have the role to ensure their needs to be fulfilled, check on their condition, and cooperate with other relevant actors.

Second, child refugees have the right to education, just like children in a normal living condition. UNHCR also stated that one of its mandate is to make sure that the child refugees have access to education. ${ }^{37}$ However, 3.7 million of 6 million schoolage refugees do not have the opportunity to go to school. ${ }^{38}$ As they grow up, the chance to pursue higher education is getting harder. It is reported that only 22 per cent of refugees in their adolescent age could attend lower secondary school, and only one per cent of them could continue to the university. ${ }^{39}$ From this condition, it can be concluded that even though child refugees are entitled to education, the lack of opportunity to receive education as a basic need remains unfulfilled. Without adequate access to education, these child refugees' dreams are difficult to be achieved. Even if there are efforts to educate the child refugees by conducting temporary schools, it should be emphasized that the type of education that is being given to the child refugees should meet their need and condition. One could give practical education that could enhance their skills which could be useful for their future.

Another challenge in the sector of education for the child refugees is the issue of prioritization between education and the fulfillment of basic needs. This problem means that there are actors who believe that education is a luxury rather

\footnotetext{
${ }^{37}$ UNHCR, "Missing out: refugee education in crisis," September 2016, accessed November 22, 2017, http://uis.unesco.org/sites/default/files/documents/missing-out-refugee-educationin-crisis_unhcr_2016-en.pdf

${ }^{38}$ Ibid.

${ }^{39}$ Ibid.
} 
than a basic need that has to be fulfilled. As reported by UNHCR, education is often be considered as less important compared to food, water, shelter, and medical care. ${ }^{40}$ Moreover, in the case of inadequate amount of funding, education is the first sector to be eliminated from the agenda. ${ }^{41}$ The failure to understand the importance of education for the child refugees might not cause any immediate harm. For instance, child refugees who do not receive assistance in the form of food and water might caused them any kinds of illness, meaning that the harm exists in an immediate time. On the contrary, child refugees who do not receive proper education might still be alive, but the consequences are waiting in the near future. Without education, they could not have the skills needed to achieve their dreams. This argument means that education is a long term need but has to be fulfilled since the early age of the child refugees.

The previous argument is linked to the last key point, which is the lack of long term solutions for the child refugees. ${ }^{42} \mathrm{~A}$ well-planned projects and efforts to give assistance to the child refugees should be prepared as early as possible. It can be concluded that the child refugees' needs are different based on their background and their current condition. However, they still have common needs that are crucial to be fulfilled to ensure their safety and security. These common needs are categorized as immediate needs, which includes the fulfillment of food, healthcare, clean water, and nutrition. As an addition to this list, education shall be included as an immediate need because it matters to the child's future.

Based on the abovementioned arguments, even if a lot of efforts have been conducted to give assistance to the child refugees, however, it has to be taken into consideration that it has to meet the needs of the child refugees based on their specific condition and their respective host country. Moreover, the initiative to

\footnotetext{
${ }^{40}$ Ibid.

${ }^{41}$ Ibid.

${ }^{42}$ UNICEF, "Refugee and Migrant Crisis in Europe: Humanitarian Situation Report \#19," January 16, 2017, accessed November 18, 2017, https://www.unicef.org/appeals/files/UNICEF_Refugee_and_Migrant_Crisis_in_Europe_R egional_Humanitarian_Situation_Report_16_Jan_2017.pdf
} 
conduct a coordinated action between the international organization and the host country shall be continued. For instance, UNICEF has cooperated with the European Member States to conduct coordinated programs to increase the wellbeing of the refugees, including the child refugees. Through the "No Lost Generation initiative," UNICEF strives to promote the programs on education, child protection, and adolescent engagement. ${ }^{43}$ However, in order to maximizing these initiatives, the previous coordinated actions that have been conducted shall be reviewed and reevaluated to analyze whether the coordinated actions have fulfill the need of child refugees based on their actual needs or not. A policy briefing on the refugee protection, migration and human rights in Europe points out the inadequacy of Europe's responses to the Syrian crisis particularly on the issue of border problems and refugee protection and a lack of coordinated action on refugees in Europe. ${ }^{44}$ Even if there are efforts to increase the wellbeing of the refugees, however, several EU member states have provided inadequate protection to them, and the efforts are still considered as uncoordinated an unbalanced. ${ }^{45}$

\section{Conclusion}

The issue of refugees in Europe could be analyzed through various lenses and level of analysis. This essay has chosen to analyze further about the issue of child refugees. Ideally, those child refugees who have suffered through perilous journey in order to arrive in Europe should receive the assistances according to their needs. It has been pointed out that the child refugees have suffered from both physical and mental wounds during the journey and after their arrival to the host

\footnotetext{
${ }^{43}$ UNICEF, "Refugee and Migrant Crisis in Europe," September 2015, accessed November 20 , 2017 , https://www.unicef.org/publicpartnerships/files/Refugee_and_migrant_children_in_Europe_ -_Sept_2015.pdf

${ }^{44}$ Eleni Frantziou, Uta Staiger, and Sarah Chaytor, "Refugee Protection Migration and Human Rights in Europe," UCL Policy Briefing, May 2014, accessed November 25, 2017, https://www.ucl.ac.uk/european-institute/ei-publications/europe-briefing-refugee.pdf ${ }^{45}$ Ibid.
} 
country. However, even though there are already efforts conducted by the government and international organizations to assist them, their actual needs are still not evenly fulfilled.

First, on the protection of child refugees, there are a lot of child refugees who still do not get adequate protection. Moreover, some European countries who supposed to ensure the protection of the child refugees closed their border so that the refugees could not get into their territory. The lack of protection for the child refugees shows that there is an urgent need to conduct a more coordinate action between the host country, the international organization, and any other relevant actors. Second, other than food, clean water, sanitation, and place to live, education shall be regarded as an immediate need. The child refugees have the right to the access to education, which will be beneficial for their future. In addition, a long term solution to ensure the protection and education for the child refugees should be well-planned and meet the needs of the child refugees in the field based on their background and their condition to ensure the betterment of their future.

\section{Bibliography}

"Migrant crisis: One million enter Europe in 2015." BBC News, December 22, 2015. Accessed on November 21, 2017. http://www.bbc.com/news/worldeurope-35158769

$10^{\text {th }}$ European Forum on the rights of the child. "The protection of children in migration," 29-30 November 2016, revised on March 29, 2017.

Clayton, Jonathan and Hereward Holland. "Over one million sea arrivals reach Europe in 2015." UNHCR official website, December 30, 2015. Accessed $\begin{array}{llll}\text { November } & 2017 . & \text { http://www.unhcr.org/afr/news- }\end{array}$ /latest/2015/12/5683d0b56/million-sea-arrivals-reach-europe-2015.html European Commission. "Communication from the Commission to the European Parliament and the Council: The protection of children in migration.” 2017. https://ec.europa.eu/home-affairs/sites/homeaffairs/files/what-we-

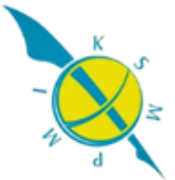


do/policies/european-agenda-migration/20170412_communication_on_the_protection_of_children_in_migration_en.pdf, 2.

Frantziou, Eleni., Uta Staiger, and Sarah Chaytor. "Refugee Protection Migration and Human Rights in Europe.” UCL Policy Briefing, May 2014. Accessed November 25, 2017. https://www.ucl.ac.uk/european-institute/eipublications/europe-briefing-refugee.pdf

Hebebrand, Johannes et al. "A first assessment of the needs of young refugees arriving in Europe: what mental health professionals need to know. Eur Child Adolesc Psychiatry, (2016)25: 1-6. https://www.escap.eu/bestanden/Care\%20(38)/Refugees/REFUGEE\%20CRISIS/refugee_editorial_january_20 16.pdf

International Organization for Migration Global Migration Data Analysis Centre. "Children and unsafe migration in Europe: Data and policy, understanding the evidence base." Accessed November 20, 2017, https://publications.iom.int/system/files/gmdac_data_briefing_series_issue5.p df

Kingsley, Patrick. "Balkan countries shut borders as attention turns to new refugee routes," The Guardian, March 9, 2016. Accessed November 28, 2017. https://www.theguardian.com/world/2016/mar/09/balkans-refugee-routeclosed-say-european-leaders

Ostrand, Nicole. "The Syrian Refugee Crisis: A Comparison of Responses by Germany, Sweden, the United Kingdom, and the United States.” Journal on Migration and Human Security 3, no. 3 (2015): 255-279.

Sergio Carrera, et al. "The EU's Response to the Refugee Crisis: Taking Stock and Setting Policy Priorities." Centre for European Policy Studies Essay no. 20 (December 2015): 1-2.

UNHCR. "Missing out: refugee education in crisis," September 2016. Accessed November 22, 2017.2 http://uis.unesco.org/sites/default/files/documents/missing-out-refugee-education-in-crisis_unhcr_2016-en.pdf

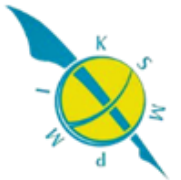


UNHCR. "Protecting Refugees: A field guide for NGOs." Accessed November 28, 2017. http://www.unhcr.org/3bb9794e4.pdf

UNHCR. "Refugee Children: Guidelines on Protection and Care." Accessed November 18, 2017. http://www.unhcr.org/protect/PROTECTION13b84c6c67.pdf

UNHCR. "The Future of Syria: Refugee Children in Crisis," November 2013. Accessed November 18, 2017. http://www.refworld.org/pdfid/529c3b4d4.pdf UNICEF. "Refugee and Migrant Crisis in Europe: Humanitarian Situation Report \#19," January 16, 2017. Accessed on November 18, 2017. https://www.unicef.org/appeals/files/UNICEF_Refugee_and_Migrant_Crisis _in_Europe_Regional_Humanitarian_Situation_Report_16_Jan_2017.pdf

UNICEF. "Refugee and Migrant Crisis in Europe." September 2015. Accessed November 20, 2017. https://www.unicef.org/publicpartnerships/files/Refugee_and_migrant_children_in_Europe_-_Sept_2015.pdf

United Nations Trust Fund for Human Security. "Human Security in the theory and practice: An overview of the Human Security Concept and the United Nations Trust Fund for Human Security.” 2009. http://www.un.org/humansecurity/sites/www.un.org.humansecurity/files/hum an_security_in_theory_and_practice_english.pdf

Victoria Metcalfe-Hough. "The migration crisis? Facts, challenges, and possible solutions.” ODI Briefing, October 2015.

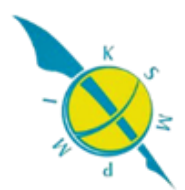

